\title{
A Study On Frustration in Fantine on Les Miserables Novel By Victor Hugo: Psychological Approach and Its Implementation
}

\author{
Amrita Titaranti, Siswantoro, Dewi Rochsantiningsih \\ English Education Department \\ Teacher Training and Education Faculty \\ Sebelas Maret University of Surakarta
}

Email: amrita.tita@yahoo.com

\begin{abstract}
Novel has its own richness which is worth exploring. It has many kinds of subject discussions. The subject of frustration is chosen based on Fantine, the most influential woman character in this novel. From her life, frustration as a psychological effect appears. The discussion is not only in literary discussion, but it is also used as teaching material as the tool to complete the need of literary teaching among senior high school students. The data consist of every sentence or conversation which reveal Fantine's thought, feeling, or behavior. They are collected by reading the novel empirically and analyzed by using flow model by Miles and Huberman (1994). The findings of the study show that (a) Fantine's evidences of frustration are anxiety, anger and aggression, apathy and depression, cognitive trouble, health disruption, and physical appearance. (b) Fantine's causes of frustration are unpredictable incident, uncontrolled incident, incident which challenges human limitation, and internal conflict. (c) Fantine's defense mechanisms are suppression, formed reaction, displacement, and denial. (d) And then summarize of Fantine's story is used as teaching reading material by putting it in lesson plan which uses curriculum 2013.
\end{abstract}

Keywords: frustration, psychological, teaching material.

\section{INTRODUCTION}

Novel is an interesting literary work. It has specific characteristics which are not possessed by other literary works such as poem, drama, etc. Novel is arranged by unique language varieties. This is in line with Eagleton (2010) who said that novel empirically deviates from daily conversation, but novel is not only arranged by many language varieties and longer words, it also reflects an obvious context in clarifying a certain cultural and social context.

Novel as a literary work overcomes language boundary that cannot be interpreted as unruled work. It is in line with Eagleton (2010) who said that literature is not merely revealing of feeling or sense, nor merely an expression of the author, it can be analyzed. But it cannot be analyzed speculatively or at random. It means that it needs a systematic or scientific study. Novel has huge components and varieties, thus research should be focused on specific kind of novel and approach which is considered related to the novel's problem.

From many novels, Les Miserables created by Victor Hugo has been chosen as the research material. The choice of the novel itself is in line with Ratna in Kusnadi \& Sutejo (2004) who said that literary research can be done by deciding the kind of literature first, then deciding the proper theories to support it. Then specific subject which is researched is the character named Fantine. The choice of Fantine is in line with 
Wellek \& Warren (1949) who said that a study on literature can be reached from study on the character in literary works.

Fantine, the most influential woman character in the novel, is created by the author by using detail explanation as a pillar of the story beside the main character, that is, Jean Valjean. She receives many injustice treatments which annoy her psychological life just to keep the story continued. Thus, frustration becomes the strongest tendency which appears as a problem to be studied. As an in dangerous situation, Fantine unconsciously fortifies her life with certain acts to make her safe or out of every distraction feeling, thought, and behavior, called defense mechanism.

Her psychological evidences, based on Atkinson (2010), are categorized in four types. Those are anxiety, anger and aggression, apathy and depression, and

cognitive trouble. Then the causes are categorized into five types: traumatic incident, uncontrolled incident, unpredictable incident, incident which challenge human limitation, and internal conflict. By meant of the evidences and causes, defense mechanisms are expressed by the types: repression, suppression, rationalization, formed reaction, projection, intellectualization, denial, and displacement.

Besides the benefit in studying literature, the novel is used to be the students reading material. The standard in deciding in what condition the novel can be used as reading material to senior high school students is determined through

Brown (2004) who shows three types of reading, those are academic reading, jobrelated reading, and personal reading. Then

to clarify the need of the students among reading material, Jeanne Call's (1983) statement is raised, she said that there are six levels of their reading: pre-reading for preschool, initial reading for elementary school, confirmation and fluency for middle school, multiple viewpoints for high school, and construction and reconstruction for college. Digging deep necessities of students is important, thus micro and macro skills are used, then for the specification of their need, reading assessment properly is made. Therefore, the types of reading which refer to the students' assessment are needed, those are, perceptive reading, selective reading, interactive reading, and extensive reading (Brown, 2004).

\section{RESEARCH METHODS}

The research used qualitative data analysis. It is told by Miles and Huberman (2010) that qualitative data analysis is used for analyzing verbal data rather than numerical data. It is proper method for analyzing a novel for the novel provides its data from words.

The data were taken from a novel entitled Les Miserables by Victor Hugo in 1862. The novel completely consists of 1263 pages from which page 111 until 265 are used as the data of the research. This research used the first serie which raises Fantine as the major character. The research was not bounded in a certain place. The most important data which is used is Les Miserables novel itself. The criteria for collecting, selecting, and analyzing data are every conversation, statement, and behavior which are related to Fantine.

The criteria of collecting data is found in volume one which is entitled Fantine, and it is put in book three until boo eight in volume one, for detail. The research is done for about seven months; three months for composing the proposal, a month for gathering the data, and three months for analyzing the data. The data are collected by reading the novel for several times for the first step, and then identify the data which related with Fantine's psychological 
condition. The data is analyzed by using flow model of qualitative data analysis which proposed by Miles and Huberman (2010). Flow model of qualitative data analysis consists of data reduction, data display, and conclusion drawing, and verification.

Psychological approach is used by doing a posteriori method or grounded theory. It goes through several processes of analysis verbal data which consists of behavior of a case or character which guide the researcher to formulate a final appropriate approach (Muyana, 2001). It is carried out by means of observation through reading the novel several times, deciding different titles in three times, and determining different approaches in two times. Psychological approach is supposed as the closest approach to the thesis problem.

\section{RESEARCH FINDINGS AND DISCUSSIONS}

The findings are divided into two parts: (a) findings about Fantine's psychological condition and (b) novel as a material for senior high school reading. Findings related to Fantine's psychological condition consisted of: evidences of Fantine's frustration, causes of Fantine's frustration, and defense mechanisms of
Fantine's frustration. Her psychological condition also has resulted lesson learn that will be given after those three main psychological discussion shown. Then findings related to novel as a reading teaching material for senior high school are explained about the need of students and its fulfillment using the novel.

\section{Fantine's psychological condition}

Fantine shows several frustration conditions which distract her behavior, thought, and feeling. It is fullfiling Atkinson's (2010) that say frustration is a condition in which people face a case which threaten their health of physic and mental. Beside the four types which have been revealed by Atkinson, Fantine shows two more types of category representing her psychological condition. Each type of category will be explained as follows:

a. Kind of Fantine's frustration and its causes

Table explains about the evidences and causes of Fantine's frustration, and then Fantine's defense mechanisms are given after it. $\mathrm{R}$ for Reflection, $\mathrm{C}$ for Cause, first number for number of part, second number for number of book, third number for number of chapter, and the last for number of page.

Table 1. Evidence and Cause

\begin{tabular}{|c|c|c|c|c|c|c|}
\hline \multicolumn{3}{|c|}{ Frustration } & \multicolumn{3}{|c|}{ Causes } & \multirow[t]{2}{*}{ Learning point } \\
\hline Forms & Types & Evidences & Evidences & Types & Forms & \\
\hline \multirow{3}{*}{ Anxiety } & \multirow{3}{*}{ Crying } & \multirow{3}{*}{$\begin{array}{l}\text { R.1.5.8.162 ...she } \\
\text { often turned aside, } \\
\text { in the midst of the } \\
\text { rest, to wipe away a } \\
\text { tear. }\end{array}$} & $\begin{array}{l}\text { C.1.5.8.162 These } \\
\text { were the moments } \\
\text { when she was } \\
\text { thinking of her } \\
\text { child; perhaps, also, } \\
\text { of the man whom } \\
\text { she had loved. }\end{array}$ & $\begin{array}{l}\text { Thinking of } \\
\text { her child and } \\
\text { her husband }\end{array}$ & $\begin{array}{l}\text { Internal } \\
\text { conflict }\end{array}$ & $\begin{array}{c}\text { Family should be } \\
\text { together, not being } \\
\text { separated in different } \\
\text { places }\end{array}$ \\
\hline & & & $\begin{array}{l}\text { C.1.3.9.131 We are } \\
\text { going; we are gone. }\end{array}$ & $\begin{array}{c}\text { Being } \\
\text { abandoned } \\
\text { by } \\
\text { Tholomyes, } \\
\text { her husband }\end{array}$ & Unpredictable & $\begin{array}{l}\text { A husband should be } \\
\text { responsible in protecting } \\
\text { his wife }\end{array}$ \\
\hline & & & $\begin{array}{l}\text { C.1.4.1.136 Then } \\
\text { she thought of } \\
\text { Tholomyes, who } \\
\text { had shrugged his } \\
\text { shoulders over his }\end{array}$ & $\begin{array}{l}\text { Passiveness } \\
\text { of } \\
\text { Tholomyes } \\
\text { about } \\
\text { Cosette, his }\end{array}$ & Unpredictable & $\begin{array}{l}\text { A father should be } \\
\text { responsible in caring his } \\
\text { child }\end{array}$ \\
\hline
\end{tabular}




\begin{tabular}{|c|c|c|c|c|c|c|}
\hline & & & $\begin{array}{l}\text { child, and who did } \\
\text { not take that } \\
\text { innocent being } \\
\text { seriously... } \\
\end{array}$ & child & & \\
\hline $\begin{array}{l}\text { Anger and } \\
\text { Agression }\end{array}$ & $\begin{array}{l}\text { Throwing } \\
\text { things }\end{array}$ & $\begin{array}{l}\text { R.1.5.10.168 } \\
\text { Fantine threw her } \\
\text { mirror out of the } \\
\text { window. } \\
\end{array}$ & $\begin{array}{l}\text { C.1.5.10.168 The } \\
\text { two teeth had been } \\
\text { extracted }\end{array}$ & $\begin{array}{l}\text { Losing her } \\
\text { teeth }\end{array}$ & $\begin{array}{l}\text { Internal } \\
\text { conflict }\end{array}$ & $\begin{array}{l}\text { A woman deserves to } \\
\text { have proper job, not by } \\
\text { selling her teeth }\end{array}$ \\
\hline \multirow{3}{*}{$\begin{array}{l}\text { Cognitive } \\
\text { Trouble }\end{array}$} & \multirow{3}{*}{ Stammering } & \multirow{3}{*}{$\begin{array}{l}\text { R.1.5.8.162 she } \\
\text { stammered a few } \\
\text { supplicating words. }\end{array}$} & $\begin{array}{l}\text { C.1.5.8.162 ......and } \\
\text { requested her, in the } \\
\text { mayor's name, to } \\
\text { leave the } \\
\text { neighborhood. }\end{array}$ & $\begin{array}{l}\text { Expeltion of } \\
\text { Fantine }\end{array}$ & $\begin{array}{l}\text { Unpredictable } \\
\text { insident }\end{array}$ & $\begin{array}{l}\text { Fantine should be } \\
\text { permitted to work } \\
\text { although she has a child } \\
\text { without a husband beside } \\
\text { her, moreover, that is a } \\
\text { right reason to let her } \\
\text { have her job to fullfil her } \\
\text { life }\end{array}$ \\
\hline & & & $\begin{array}{l}\text { C.1.5.8.162 this was } \\
\text { the very month } \\
\text { when the } \\
\text { Thernardiers, after } \\
\text { having demanded } \\
\text { twelve francs } \\
\text { instead of six, had } \\
\text { just exacted fifteen } \\
\text { francs instead of } \\
\text { twelve. }\end{array}$ & $\begin{array}{l}\text { Thernardiers } \\
\text { ' exaction }\end{array}$ & $\begin{array}{l}\text { Unpredictable } \\
\text { and } \\
\text { uncontrolled } \\
\text { insident }\end{array}$ & $\begin{array}{l}\text { One should not exact a } \\
\text { poor mother, but help her } \\
\text { to ease her burden by } \\
\text { take care the child }\end{array}$ \\
\hline & & & $\begin{array}{l}\text { C.1.5.8.162 She } \\
\text { could not leave the } \\
\text { neighborhood; she } \\
\text { was in debt for her } \\
\text { rent and furniture. } \\
\text { Fifty francs was not } \\
\text { sufficient to cancel } \\
\text { this debt. }\end{array}$ & $\begin{array}{l}\text { Fantine's } \\
\text { debt }\end{array}$ & $\begin{array}{l}\text { Uncontrolled } \\
\text { insident }\end{array}$ & $\begin{array}{l}\text { By the condition, using } \\
\text { money for something } \\
\text { usefull is better than } \\
\text { using it for merely much } \\
\text { pleasure }\end{array}$ \\
\hline $\begin{array}{l}\text { Apathy And } \\
\text { Depression }\end{array}$ & Afraid & $\begin{array}{l}\text { R.1.5.8.163 she was } \\
\text { advised to see the } \\
\text { mayor; she did not } \\
\text { dare. }\end{array}$ & $\begin{array}{c}\text { C.1.5.10.166 She } \\
\text { had long shared the } \\
\text { universal veneration } \\
\text { for Father } \\
\text { Madeleine; yet, by } \\
\text { dint of repeating to } \\
\text { herself that if was } \\
\text { he who had } \\
\text { discharged her, that } \\
\text { he was the cause of } \\
\text { her unhappiness, } \\
\text { she came to hate } \\
\text { him also, and most } \\
\text { of all. }\end{array}$ & $\begin{array}{l}\text { Deep honour } \\
\text { to Father } \\
\text { Madeleine }\end{array}$ & $\begin{array}{l}\text { Internal } \\
\text { conflict }\end{array}$ & $\begin{array}{l}\text { An honour should not } \\
\text { make a fear in someone's } \\
\text { heart, it should make a } \\
\text { trust }\end{array}$ \\
\hline \multirow{3}{*}{$\begin{array}{l}\text { Physical } \\
\text { Disruption }\end{array}$} & \multirow{3}{*}{ Cough } & \multirow{3}{*}{$\begin{array}{l}\text { R.1.5.10.169 she } \\
\text { coughed a great } \\
\text { deal. }\end{array}$} & $\begin{array}{l}\text { C.1.5.10.168-169 } \\
\text { She had no longer a } \\
\text { bed; a rag which } \\
\text { she called her } \\
\text { coverlet, a mattress } \\
\text { on the floor,... }\end{array}$ & $\begin{array}{l}\text { having less } \\
\text { things to } \\
\text { warm her } \\
\text { body in her } \\
\text { house }\end{array}$ & $\begin{array}{l}\text { Insident which } \\
\text { challenge } \\
\text { human } \\
\text { limitation }\end{array}$ & $\begin{array}{l}\text { She learned to adequate } \\
\text { herself with the things } \\
\text { she had }\end{array}$ \\
\hline & & & $\begin{array}{l}\text { C.1.5.10.169 she } \\
\text { went out with dirty } \\
\text { caps. Whether from } \\
\text { lack of time or from } \\
\text { indifference, she no } \\
\text { longer mended her } \\
\text { linen. As the heels } \\
\text { wore out, she } \\
\text { dragged her } \\
\text { stockings down into } \\
\text { her shoes. This was } \\
\text { old and worm out, } \\
\text { with scraps of } \\
\text { calico which tore at } \\
\text { the slightest } \\
\text { movement. }\end{array}$ & $\begin{array}{l}\text { Having less } \\
\text { clothes to } \\
\text { warm her } \\
\text { body }\end{array}$ & $\begin{array}{l}\text { Insident which } \\
\text { challenge } \\
\text { human } \\
\text { limitation }\end{array}$ & $\begin{array}{l}\text { She learned to adequate } \\
\text { herself with the things } \\
\text { she had }\end{array}$ \\
\hline & & & $\begin{array}{c}\text { C.1.5.9.165 Excess } \\
\text { of toil wore out } \\
\text { Fantine, }, . .\end{array}$ & The toil & $\begin{array}{l}\text { Insident which } \\
\text { challenge } \\
\text { human } \\
\text { limitation }\end{array}$ & $\begin{array}{l}\text { She learned the important } \\
\text { of health }\end{array}$ \\
\hline
\end{tabular}




\begin{tabular}{|c|c|c|c|c|c|c|}
\hline \multirow{6}{*}{$\begin{array}{l}\text { Physical } \\
\text { Appearance }\end{array}$} & \multirow{6}{*}{$\begin{array}{l}\text { Old body } \\
\text { appearance }\end{array}$} & \multirow{6}{*}{$\begin{array}{l}\text { R.1.7.6.227 } \\
\text { physical suffering } \\
\text { had completed the } \\
\text { work of moral } \\
\text { suffering. This } \\
\text { creature of five and } \\
\text { twenty had a } \\
\text { wrinkled brow, } \\
\text { flabby cheecks, } \\
\text { pinched nostrils, } \\
\text { teeth from which } \\
\text { the gums had } \\
\text { receed, a leaden } \\
\text { complexion, a bony } \\
\text { neck, prominent } \\
\text { shoulder blades, } \\
\text { frail limbs, a clayey } \\
\text { skin, and her golden } \\
\text { hair was growing } \\
\text { out sprinkled with } \\
\text { gray. Alas! How } \\
\text { illness improvises } \\
\text { old age! }\end{array}$} & $\begin{array}{l}\text { C.1.5.10.168-169 } \\
\text { She had no longer a } \\
\text { bed; a rag which } \\
\text { she called her } \\
\text { coverlet, a mattress } \\
\text { on the floor,... }\end{array}$ & $\begin{array}{l}\text { having less } \\
\text { things to } \\
\text { protect her } \\
\text { body in her } \\
\text { house }\end{array}$ & $\begin{array}{l}\text { Insident which } \\
\text { challenge } \\
\text { human } \\
\text { limitation }\end{array}$ & $\begin{array}{l}\text { She learned to adequate } \\
\text { herself with the things } \\
\text { she had }\end{array}$ \\
\hline & & & $\begin{array}{l}\text { C.1.5.10.169 ... she } \\
\text { no longer mended } \\
\text { her linen. As the } \\
\text { heels wore out, she } \\
\text { dragged her } \\
\text { stockings down into } \\
\text { her shoes. This was } \\
\text { old and worm out, } \\
\text { with scraps of } \\
\text { calico which tore at } \\
\text { the slightest } \\
\text { movement. }\end{array}$ & $\begin{array}{l}\text { having less } \\
\text { clothes to } \\
\text { make her } \\
\text { appearance } \\
\text { looked fresh }\end{array}$ & $\begin{array}{l}\text { Insident which } \\
\text { challenge } \\
\text { human } \\
\text { limitation }\end{array}$ & $\begin{array}{l}\text { She learned to adequate } \\
\text { herself with the things } \\
\text { she had }\end{array}$ \\
\hline & & & $\begin{array}{c}\text { C.1.5.9.165 Excess } \\
\text { of toil wore out } \\
\text { Fantine, }, . .\end{array}$ & The toil & $\begin{array}{c}\text { Insident which } \\
\text { challenge } \\
\text { human } \\
\text { limitation } \\
\end{array}$ & $\begin{array}{l}\text { She learned the important } \\
\text { of health }\end{array}$ \\
\hline & & & $\begin{array}{c}\text { C.1.5.10.169 } \\
\text { Seventeen hours of } \\
\text { toil, and nine sous a } \\
\text { day! Her creditors } \\
\text { were more pitiless } \\
\text { than ever. }\end{array}$ & $\begin{array}{l}\text { Less of rest, } \\
\text { being chased } \\
\text { by her debt }\end{array}$ & $\begin{array}{l}\text { Insident which } \\
\text { challenge } \\
\text { human } \\
\text { limitation }\end{array}$ & $\begin{array}{c}\text { She learned the important } \\
\text { of health and saving } \\
\text { money for most } \\
\text { important necessity }\end{array}$ \\
\hline & & & $\begin{array}{l}\text { C.1.6.1.182 That } \\
\text { handful of snow } \\
\text { applied to her bare } \\
\text { skin between her } \\
\text { shoulder blades had } \\
\text { brought about a } \\
\text { sudden suppression } \\
\text { of perspiration, as a } \\
\text { consequence of } \\
\text { which the malady } \\
\text { that had been } \\
\text { shouldering within } \\
\text { her for many years } \\
\text { was violently } \\
\text { developed at last. } \\
\text { At that time people } \\
\text { were beginning to } \\
\text { follow the fine } \\
\text { Laennec's fine } \\
\text { suggestions in the } \\
\text { study and treatment } \\
\text { of chest maladies. }\end{array}$ & $\begin{array}{l}\text { Being chased } \\
\text { with a } \\
\text { handful of } \\
\text { snow }\end{array}$ & $\begin{array}{l}\text { Unpredictable } \\
\text { insident }\end{array}$ & $\begin{array}{c}\text { Society should not rudely } \\
\text { behave to poor woman } \\
\text { even she is a prostitute }\end{array}$ \\
\hline & & & $\begin{array}{c}\text { C.1.6.1.180 A } \\
\text { burning fever had } \\
\text { come. }\end{array}$ & Fever & $\begin{array}{l}\text { Uncontrolled } \\
\text { insident }\end{array}$ & $\begin{array}{l}\text { She learned the important } \\
\text { of health }\end{array}$ \\
\hline
\end{tabular}

In more detail, table 1 is elaborated in the following.

\section{1) Evidences of Fantine's frustration}

Anxiety is a normal response for facing problems. It can appear in many forms which represent one's feeling and response toward the problem. Fantine's anxiety shows several forms from her behavior, her feeling, her thought, or her words which indicate anxiety. Six forms shown by her are crying for a husband who has abandoned her and her child and crying for her child who has lived in different city, hating the mayor of the city for-because of misunderstanding - firing her from her job, feeling insecure for pitiless debt collector who has chased her while she did not have money to pay, afraid of being prisoner by injustice law, weeping and thinking every night for remembering each problem that she could not solve, and confused for she has to do if she loosed her job.

Anger and aggression have same characteristics which make them be 
categorized into one group. Those forms show Fantine's violently words or acts by one's response toward frustration causes. Four forms of Fantine's anger and aggression are throwing her mirror out of the window, amucking to person who humiliate her, spitting to person, and rudely talk to her neighbors and doctor.

The same as anger and aggression, apathy and depression have same characteristics which make them be categorized into one group. Those forms show Fantine's cringing among normal attitude, society, and possibility in hoping better life. Those forms are afraid of complaining a possibility of injustice to the mayor of the city, ashamed to go out among people, and hopeless for help which would come.

Cognitive trouble might appear as people's response toward problem. People's thoughts in seeking solution tend to fulfill people's mind thus thinking of simple and normal thing would be distracted. These appearances: stammering while she was ordered to leave the neighborhood, doing something unconsciously such as received a letter about her child's condition and crushed it all day long, and talks indifferently as an act for her impatient while waiting for her child.

Beside those four types, Fantine shows other types:

Health disruption which is shown as a form of frustration is cough. She has bad cough and got worse day by day. Seeming she did not take a medicine to cure her ill, but bearing it while she keeps working.

Physical appearances which indicates Fantine's frustration are old body appearance in which Fantine looked older than her real age, it is seen by her face, her body, her skin, and her hair; then Fantine's countenance appearance which represent her sad feeling and her poverty; gloomy which is shown by unsmiling lips, and her countenance appearance which represent her health for she looked pale.

\section{2) Causes of Fantine's frustration}

Fantine's psychological condition not only consisted of the evidence of form, it also consisted of causes of the form and the solution which Fantine took psychologically. The causes are divided into five forms, those are, traumatic incident, unpredictable incident, uncontrolled incident, and incident which challenge human limitation, and internal conflict (Atkinson, 2010). From those categories, Fantine fulfilled four of them. The specific explanation is explained as follows:

By unpredictable incident, Fantine cannot imagine cases which appeared following the time or her decision. The cases were surprising her and demanding for her adaptation. Those cases are the case while she was abandoned by her husband named Tholomyes, uncaring of Tholomyes toward his own child with Fantine, sly creditor who gave too much pressure, injustice incarceration which was given by Javert to Fantine, continually increasing debt by Thernardiers as a cost of entrusting a child which seemed like she was exacted, expel of Fantine for women's gossip by its reason, being verbally and physically humiliated for Fantine work as a prostitute, being isolated from society, having less of pleasure, ever been in a jobless condition, and having several experiences of misunderstanding.

These are causes in which Fantine could realize before but she did not have power to manage it by her strength. Instead, she needed much help but she almost never got it. Those causes are pitiless creditor who gave her much pressure because she could not pay her debt yet; Fantine's wish in seeing her child who had been entrusted to, unfortunately, a sly family named 
Thernardiers, she thought of her child so much; increasing debt which made her more pressured for she did not know how to pay it; her toil and few earning that she got; being found that Fantine had a child without a husband; and serious ill such as fever and cough.

These are incidents which can be predicted and controlled, but as those happened continually; huge strength was needed to bear it. The incidents needed much Fantine's adaptation, and by the time she failed to hold those burdens, she got frustration. Those incidents are the moment when she did not have enough house hold utilities and clothes to warm, protect, and beautify her body and her appearance; when she worked very hard everyday and got few hours to take a rest; and when she was chased by her creditor to pay her debt which seemed impossible to fulfill.

The conflicts appeared in Fantine's consideration among things which guided to consequences while they were decided. Sometime it was a little unrealized wishing. Those internal conflicts were the moment when she thought about her child and her husband; when she sold her hair so that she loosed her beauty; when she sold her teeth so that she felt worse than before; and when she put a deep honor to the mayor but unpredictably fired her from the job.

By knowing Fantine's evidences and causes of frustration, people can learn many principles about woman right, the need of abandoned wife, the way of threatening a woman prostitute, the precious of a child, and the way of honoring people's life.
Through Fantine, people can learn that many obstacles come to every single person, but the most important thing is keep struggling and hoping. Fantine is an ordinary woman, but since her problem came, she shows a strong character, and then the character is the most important thing that human has. Through the society, people can learn that gossiping, judging, and abandoning an unfortunate woman for she is part of society is not right.

The novel also teaches to let a poor prostitute woman who does not has a husband to be helped, not to be gossiped or abandoned. Many of her problems are worth supporting by society. Her problems actually should be the reason of people's support. No one can hide his or her fault in their whole life, thus people's fault do not a reason to judge them, but a reason to help them.

\section{b. Defense mechanisms of Fantine's frustration}

People tend to build a wall to protect themselves from being hurt again. It is done by Fantine too although she actually was created as an honest woman in which running was not her way to solve a problem, it happened psychologically. She builds several kinds of defense mechanisms so that she can run from her frustration for a while. Defense mechanisms which are used by Fantine are shown in a table 2. D for defense mechanism, first number for number of part, second number for number of book, third number for number of chapter, and the last for number of page. 
Table 2. Defense Mechanism

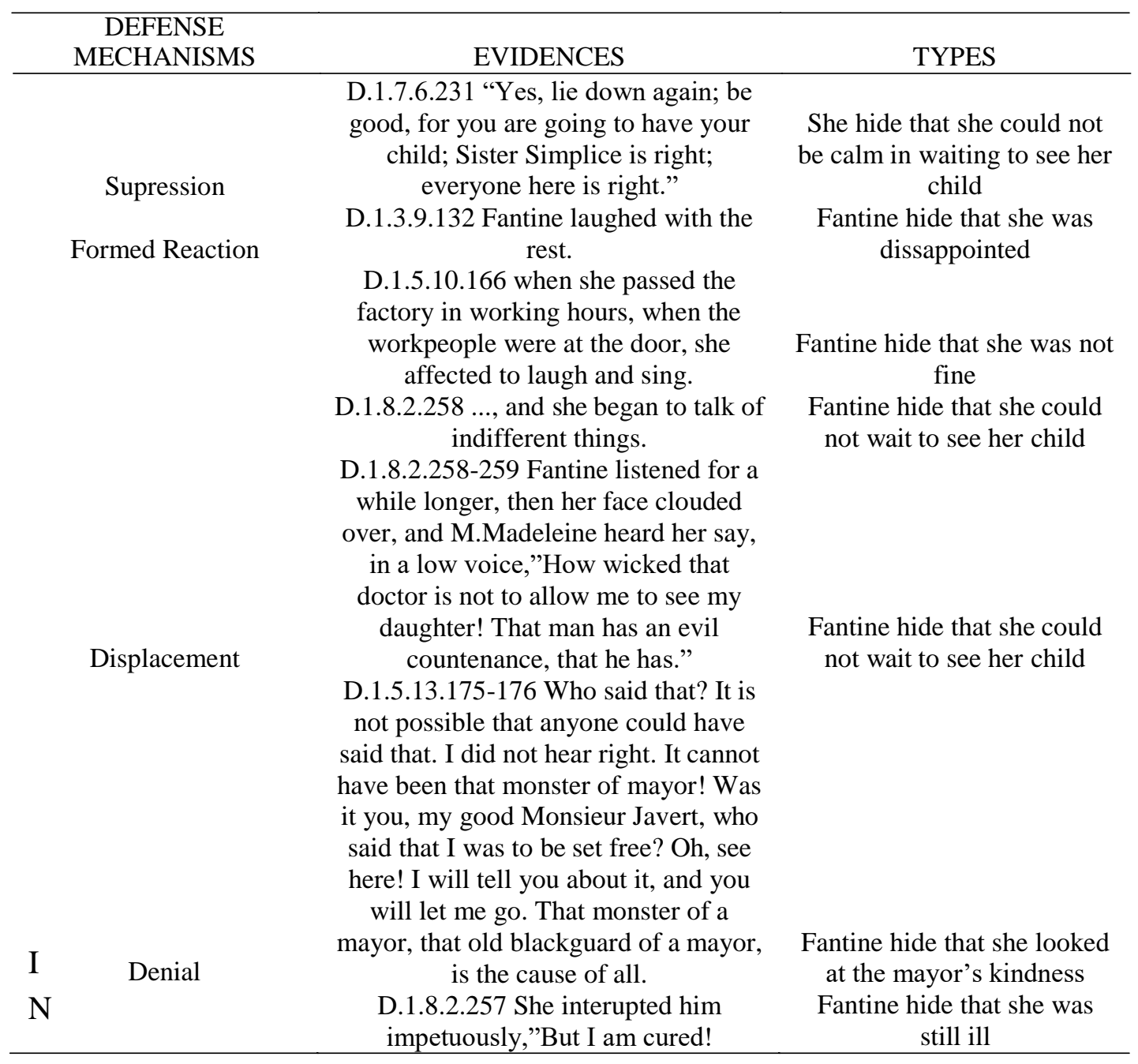

In table 2, Fantine showed psychological reaction which is called defense mechanism. She unconsciously behave to protect herself from being hurted by people. She did not always protect herself with defense mechanism, it was proved from the data that she tend to solve her problems logically. But for certain occasion, defense mechanism appeared in coping her unbearable burdens.

When Fantine has not seen her daughter for long time, holding her willing to see her child was almost impossible. She showed that she was angry with the doctor when the doctor advised her to take a rest; she also could not control her mind for what she had to say, what to feel, and what to think. Psychological response for her condition encourages her to suppress her huge willing by following people's advice to her to lay down and having nice attitude.

Fantine has been in many conditions which disappointed her. Some of those conditions are responded honestly by showing her true thinking and feeling, but some of them are not. There are conditions when Tholomyes abandoned her, when she was fired from her job, and when she could not wait for seeing her child; those conditions were responded dishonestly. Fantine pretended to be fine for those people's decision and condition by showing her fake smile and laugh and talking something indifferent.

Fantine could not wait for any longer when the mayor promised her to meet them. She shows her emotions whether they are 
good or bad. When she showed her bad emotion-as her response for waiting for Cosette - she could spilled her anger out to people around her, include the doctor who asked her to take a rest. She thought that she was forbidden to see her child. Her improper spilling emotion is a kind of displacement.

Fantine ever tried to deny the obvious facts for the facts had thrown her away from her willing to hate person and to follow her wish. Her acts were called denial. Those happened when she felt to be disappointed by the mayor of the city for firing her out from her job, but when she would be prisoner, the mayor came and saved her so that she did not need to be prisoner; and when she was ill, but she wanted to see her child, when she was asked to take a rest, she did not want and told that she had been cured.

\section{Novel as a reading material for senior} high school

\section{a. Basic of implementing a novel to reading material}

The novel not only results in a matter of moral values which is studied by psychological approach, but also results a learning material for language learning. It is normality while a product of language then becomes a material for language learning, so that the learners get their learning by authentic material.

The novel is included in academicreading for it is used in education area, although novel is often included in personal reading. It is implemented based on students' need which is seen by their age, that is 14 to 18 in which deep understanding and larger viewpoint are learnt.

From those students' need, the novel is made as students' material and assessment by seeing proper assessment for senior high school students, that is, interactive reading. From interactive reading types of assessment, the material which is made consisted of combination among formedfocused and meaning-focused in which meaning-focused was prominent. Proper material for this necessity is making several paragraphs.

For specific criteria, both micro and macro skill should meet: a)macro skills: infer context that is not explicit by using background knowledge, from described events, ideas, etc. , infer links and connections between events, deduce causes and effects, and detect such relations as main idea, supporting idea, new information, given information, generalization, and exemplification, b)micro skill: recognize cohesive devices in written discourse and their role in signaling the relationship between and among clauses. Then, for the novel is a kind of narrative text, it also implemented in narrative assessment.

The implementation of using the novel for senior high school students is also adjusted with 2013 curriculum for the curriculum is the newest curriculum for its application. Based on the curriculum, lesson plan is made following 2013 curriculum which consists of observing, questioning, exploring, and associating as the part of it. Several forms of assessment require in the lesson plan to fulfill 2013 curriculum's requirement in making a lesson plan.

\section{b. Lesson Plan of teaching reading using}

\section{Les Miserables Novel}

The implementation of using a novel as a teaching material is written in a lesson plan. The implementation is supposed to do in tenth grade of SMA Negeri 1 Karanganyar. The teaching material focuses on reading narrative. The implementation also guide the students to fulfill main competencies and basic competencies, then the indicators for fulfilling those competencies are to identify narrative structure in narrative text, deciding main 
sentence from a paragraph in narrative text, finding detail information from the text, and enable in making a narrative text. This learning using a novel is purposed to guide the students in fulfilling those indicators.

Learning material consists of learning about narrative text which includes of definition, purpose, text organization, and language features. The method which is used is scientific method as a method which normally used in curriculum 2013. Learning media which is used are power point to show the material, video about Les Miserables movie-which is taken from YouTube, and worksheet for students practice.

Learning activity is done by following these steps: opening; main activity which consists of observing, questioning, exploring, and associating; and closing. Les Miserables novel is used in main activity by recognizing it first to the students from the movie. The novel is used by summarizing a story about Fantine into several paragraphs in narrative text. This summarizing method is purposed to ease the students in getting whole information in short time. It is also a way in getting students' attention toward novel as language learning. By the paragraphs, students should analyze the text and get detail or the main thought. The paragraph also functioned as an example of making a narrative text. After the learning process is done, students are assessed by three assessment techniques: written test, attitude assessment, and pair assessment.

A novel, whether it is used for getting information or enjoying the experience of reading (Kiefer, 2010), unconsciously or consciously influence the readers. It is supported by an expert who said that the text people read can touch their thoughts and feelings (Louise Rosenblatt in Kiefer, 2010). It means that whether the novel is used as a personal reading or academic reading, the novel influences the readers' thoughts and feeling. It also may influence their behavior, attitude, principle, or character for the novel has changed their mind about certain things (Kusnadi et all, 2010). As literary book, the novel not only brings merely amusement to the reader, but also moral values contained in, the more people read literature, the more people become wiser (Kusnadi et all, 2010). As teaching material, a novel brings students a source of learning language and several examples of moral values, for a study would not be enough if only getting knowledge. It is positive for people who read literature are taught by it.

\section{CONCLUSIONS AND SUGGESTIONS}

Novel is a language product which is worth studying for any angle. As it is a language product, it can be used to learn the language itself. Values which are brought by the novel and many kinds of ways of teaching using novel attest for the worth of novel not only to be studied, but also to be used for teachers to teach their students.

The research suggests that it is essential for English students not to be doubtful in raising literature as their research and for English teachers to raise literature especially novel as their material of teaching.

English students should be allowed to use any product of language including literature or novel as specific material, to develop students' learning in many aspects of language. Such as the structure or several kinds of studies from various methods. English teachers or candidates of English teachers should apply novel as one of many ways in creating interesting and creative material for students. They could encourage them to learn English by reading a novel.

Policy maker in school and headmaster have to facilitate English 
language teachers with books about teaching using literature, so that they can get more knowledge about how literature should be taught in their classes.

\section{BIBLIOGRAPHY}

Atkinson, Rita L. 2010. Pengantar Psikologi Edisi Ke Sebelas Jilid Satu. Batam. Interaksara.

Brown, H. Douglas. 2004. Language Assessment: Principles and Classroom Practices. New York. Pearson Education, Inc

Chall, Jeanne. 1983. Stages of Reading Development. New York: McGraw Hill. pp. 10-24. Retrieved from http://newlearningonline.com/literaci es/chapter-14/chall-on-stages-ofreading-development

Eagleton, Terry. 2010. Teori Sastra: Sebuah Pengantar Komprehensif. Yogyakarta. Jalasutra.
Hugo, Victor. 2012. Les Miserables. San Diego. Canterbury Classics/Baker \& Taylor Publishing Group.

Kusnadi \& Sutejo. 2010. Kajian Prosa: Kiat Menyisir Dunia Prosa. Yogyakarta. Pustaka Felicha.

Kiefer, Barbara Zulandt. 2010. Charlotte Huck's Children's Literature. New York. McGraw-Hill Companies, Inc.

Milles, Matthew and A. Michael Huberman. 1984. Qualitative Data Analysis: A Source Book of New Methods. London. Sage Publication.

Mulyana, Deddy. 2003. Metodologi Penelitian Kualitatif: Paradigma Baru Ilmu Komunikasi dan Ilmu Sosial Lainnya. Bandung. PT. Remaja Rosdakarya.

Wellek, Rene and Austin Warren. 1949. Theory of Literature. New York. Harcourt, Brace and Company. 